\section{Dynamics of Microbial Colonization of the Oral Cavity in Newborns}

Paulo Nelson-Filho, Izabela Gonçalves Borba, Késsia Suênia Fidelis de Mesquita, Raquel Assed Bezerra Silva, Alexandra Mussolino de Queiroz, Léa Assed Bezerra Silva
Department of Pediatric Dentistry, School of Dentistry of Ribeirão Preto, University of São Paulo, Ribeirão Preto, SP, Brazil

Correspondence: Prof. Dr. Paulo Nelson Filho, Av. do Café, s/n, Monte Alegre, 14040-904 Ribeirão Preto, SP, Brasil. Tel: +55-16-36024786. Fax: +55-16-3633-0999. e-mail: nelson@forp.usp.br

\begin{abstract}
The host defense mechanisms are not well developed in neonates. The aim of this study was to evaluate the dynamics of microbial colonization of the oral cavity in newborns. Eighty-one samples of the oral microbiota were obtained from 51 healthy newborns 10 min to $53 \mathrm{~h}$ after birth by gently rubbing sterile swabs onto the surface of the tongue, cheek mucosa, alveolar process and palate. After microbiological processing, counting of the colony forming units of streptococci, staphylococci and Gram-negative aerobic bacilli was performed. Between $10 \mathrm{~min}$ and $8 \mathrm{~h}$, Staphylococcus epidermidis was detected in $30.7 \%$ of the samples; between 8 and 16 h, S. epidermidis was detected in $69.5 \%$ of the samples and streptococci in 56.5\% of the samples; between 16 and $24 \mathrm{~h}$, S. epidermidis, streptococci and S. aureus were detected in $77.78 \%, 85.18 \%$ and $37.03 \%$ of the samples, respectively. Between 24 and $53 \mathrm{~h}$, S. epidermidis was detected in $88.89 \%$, streptococci in $94.4 \%$ and S. aureus in 33.3\% of the samples. Mutans streptococci were not detected in any of the samples. The adoption of strict hygienic measures by the mother and the nursing staff should be emphasized to avoid or at least delay the occurrence of infections caused by microorganisms in newborns. In addition, hospital procedures must be aseptic and invasive interventions must be minimized.
\end{abstract}

Key Words: newborns, defense, microbial colonization, microorganisms.

\section{Introduction}

Most bacterial infections in neonates are usually acquired during or immediately after delivery (1). The host defense mechanisms in neonates are not well developed at the moment of birth and some commensals may become opportunistic pathogens, particularly in compromised babies who stay in the hospital for treatment of congenital abnormalities (1-5). Premature infants in neonatal intensive care units (NICU) (6) and those undergoing invasive life-saving medical interventions are at greater risk of developing infection (7).

Vaginal delivery inevitably results in exposure of the newborn to the normal maternal genital tract microflora (8). Although the newborn's oral cavity is usually free microorganisms $(9,10)$, colonization begins within a few hours after birth with microorganisms from the mother, nurses and sometimes from the environment (10). At birth and during the first months of life, the oral mucosa surfaces of babies can provide niches for bacterial colonization (3). It has been demonstrated that 8 days after birth, there is considerable variability in oral bacteria, and both aerobes (9) and anaerobes (11) can be detected in the oral cavity. The Gram-positive bacterial commensal Streptococcus salivarius is a pioneer colonizer of the human oral cavity $(1,10)$, being detected from $8 \mathrm{~h}$ after birth (1). Large populations persist at this site for the host's lifetime $(9,12)$, and this bacterial species represents up to $98 \%$ of the total oral microbiota until the eruption of teeth (13).

The metabolic activity of pioneer species alters the oral environment, providing acceptable conditions for colonization by other microbial species (10). Before tooth eruption, aerobic microorganisms (streptococci and staphylococci) are prevalent in the oral microbiota, with predominance of facultative microorganisms (14).

Interventions sustaining those who are hospitalized can result serious infections due to common nosocomial pathogens, particularly coagulase-negative staphylococci bacteria (CoNS) (7). Staphylococcus aureus $(2,4)$, a coagulase-positive staphylococci bacterium, and $S$. epidermidis (5), a coagulase-negative staphylococci bacterium, are the most common cause of nosocomial infections in newborns, resulting in considerable morbidity and mortality (15).

Different mutans streptococci species may cause of several pathologies. Streptococcus mutans and S. sobrinus, for example, are important species associated with dental caries (16) and colonize the oral cavity after tooth eruption. However, S. salivarius is present naturally on the tongue and cheek mucosa because it has a unique ability to adhere to these surfaces (17). S. sanguinis colonization in infants occurs during a small "window of infectivity" around the age of 9 months. This colonization is tooth-dependent and is associated with the time of tooth emergence, but the levels of $S$. sanguinis decrease after mutans streptococci colonization (18).

The objective of this study was to assess when and which microorganisms can be detected between $10 \mathrm{~min}$ and 53 $\mathrm{h}$ after birth in samples from the oral cavity of newborns 
at a nursery in a university hospital.

\section{Material and Methods}

Eighty-one samples of the oral microbiota were obtained from 51 newborns ( 32 males and 19 females) after granting written parental consent and authorization from the Head of the Department of Pediatrics, in a university hospital.

Newborns of mothers who had no complications during pregnancy were selected, regardless of the form of delivery (vaginal or caesarean section). Only healthy newborns delivered at term, with appropriate weight for the gestational age and who were not under medication participated in this study. All newborns were under continued exclusive breast-feeding.

Bacterial samples for microbiological analysis were collected from the neonates in the birthing room within $10 \mathrm{~min}$ to $53 \mathrm{~h}$ after birth by gently rubbing the surface of tongue, cheek mucosa, alveolar process and palate with sterile swabs. Immediately after sample collection, the swabs were stored in sterile test tubes containing $1 \mathrm{~mL}$ of phosphate buffered saline (PBS). Samples were grown on Mitis Salivarius (MS) (Difco, Detroit, MI, USA) agar in 10x60 mm Petri dishes and on modified SB-20 (SB-20M) (19), Agar Ni and Mac Conkey (MC) (Difco) culture media in 20x100 mm Petri dishes.

Using a sterile pipette, $0.05 \mathrm{~mL}$ of each sample was

Table 1. Microbiological analysis of samples $(n=13)$ between 10 min and $8 \mathrm{~h}$ after birth

\begin{tabular}{|c|c|c|c|c|c|}
\hline \multirow{2}{*}{ Sample } & \multicolumn{2}{|c|}{ streptococci } & \multicolumn{2}{|c|}{ staphylococci } & \multirow{2}{*}{ GNAB } \\
\hline & cfu & S. mutans & S. aureus & S. epidermidis & \\
\hline 1 & 0 & 0 & - & - & - \\
\hline 2 & 0 & 0 & - & - & - \\
\hline 3 & 0 & 0 & - & - & - \\
\hline 4 & 0 & 0 & - & - & - \\
\hline 5 & 0 & 0 & - & - & - \\
\hline 6 & 0 & 0 & - & - & - \\
\hline 7 & 0 & 0 & - & + & - \\
\hline 8 & 0 & 0 & - & + & - \\
\hline 9 & 0 & 0 & - & - & - \\
\hline 10 & 0 & 0 & - & - & - \\
\hline 11 & 0 & 0 & - & - & - \\
\hline 12 & 0 & 0 & - & + & - \\
\hline 13 & 0 & 0 & - & + & - \\
\hline
\end{tabular}

+: Positive bacterial growth. -: Negative bacterial growth. GNAB: Gram-negative aerobic bacilli. collected and spread onto the MS agar surface using a sterile bent glass rod as the spreading device. Then, 0.50 $\mathrm{mL}$ of each sample was subjected to serial decimal dilutions of up to $10^{-4}$ in PBS, and $0.05 \mathrm{~mL}$ of the resulting dilutions was sown on the MS agar surface. After seeding, the Petri dishes were incubated in anaerobic jars using the candle flame method at $37^{\circ} \mathrm{C}$ for $48 \mathrm{~h}$.

In the SB-20M medium, the samples were directly inoculated with cotton swabs, providing 5 samples per dish and the Petri dishes were incubated in anaerobic jars using the candle flame method at $37^{\circ} \mathrm{C}$ for $48 \mathrm{~h}$. Also, other 5 samples per dish were seeded in the $\mathrm{MC}$ and Ni media. The $\mathrm{Ni}$ dishes were incubated at $37{ }^{\circ} \mathrm{C}$ for $48 \mathrm{~h}$ and the MC dishes were incubated at $37^{\circ} \mathrm{C}$ for $24 \mathrm{~h}$.

After the incubation period, the number of colony

Table 2. Microbiological analysis of samples $(\mathrm{n}=13)$ between $8 \mathrm{~h}$ and $16 \mathrm{~h}$ after birth

\begin{tabular}{|c|c|c|c|c|c|}
\hline \multirow{2}{*}{ Sample } & \multicolumn{2}{|c|}{ streptococci } & \multicolumn{2}{|c|}{ staphylococci } & \multirow{2}{*}{ GNAB } \\
\hline & cfu & S. mutans & S. aureus & S. epidermidis & \\
\hline 14 & 200 & 0 & - & - & - \\
\hline 15 & 0 & 0 & - & - & - \\
\hline 16 & 40 & 0 & - & - & - \\
\hline 17 & 0 & 0 & - & - & - \\
\hline 18 & 0 & 0 & - & + & - \\
\hline 19 & 60 & 0 & - & + & - \\
\hline 20 & 0 & 0 & - & + & + \\
\hline 21 & 0 & 0 & - & + & - \\
\hline 22 & 1,050 & 0 & - & + & - \\
\hline 23 & 670,000 & 0 & - & + & - \\
\hline 24 & 80 & 0 & - & + & - \\
\hline 25 & 0 & 0 & - & + & - \\
\hline 26 & 18,700 & 0 & - & + & - \\
\hline 27 & 0 & 0 & - & - & - \\
\hline 28 & 0 & 0 & - & + & - \\
\hline 29 & 550,000 & 0 & - & + & - \\
\hline 30 & 5,400 & 0 & - & + & - \\
\hline 31 & 0 & 0 & - & - & - \\
\hline 32 & 4,600 & 0 & - & + & - \\
\hline 33 & $3,800,000$ & 0 & - & + & - \\
\hline 34 & 158,000 & 0 & - & + & - \\
\hline 35 & 0 & 0 & - & - & - \\
\hline 36 & 3,400 & 0 & - & + & - \\
\hline
\end{tabular}

+: Positive bacterial growth. -: Negative bacterial growth. GNAB: Gram-negative aerobic bacilli. 
forming units (cfu) of total streptococci (viridans) in the MS medium, mutans streptococci in the SB-20M medium, S. aureus and S. epidermidis in the Ni medium, and Gramnegative aerobes in the MC medium were counted with a stereoscopic microscope.

\section{Results}

Between $10 \mathrm{~min}$ and $8 \mathrm{~h}$ after birth, S. epidermidis was detected in 4 of the 13 samples. In the other 9 samples, there was no bacterial growth until $8 \mathrm{~h}$ (Table 1).

Table 3. Microbiological analysis of samples $(\mathrm{n}=27)$ between $16 \mathrm{~h}$ and $24 \mathrm{~h}$ after birth

\begin{tabular}{|c|c|c|c|c|c|}
\hline \multirow{2}{*}{ Samples } & \multicolumn{2}{|c|}{ streptococci } & \multicolumn{2}{|c|}{ staphylococci } & \multirow{2}{*}{ GNAB } \\
\hline & cfu & S. mutans & S. aureus & S. epidermidis & \\
\hline 37 & 60 & 0 & - & + & - \\
\hline 38 & 810 & 0 & - & + & - \\
\hline 39 & 0 & 0 & + & + & _- \\
\hline 40 & 330 & 0 & - & + & - \\
\hline 41 & 0 & 0 & - & + & - \\
\hline 42 & $10,400,000$ & 0 & - & + & - \\
\hline 43 & 0 & 0 & - & - & - \\
\hline 44 & 340 & 0 & - & + & + \\
\hline 45 & 53,000 & 0 & - & - & - \\
\hline 46 & 660 & 0 & + & - & - \\
\hline 47 & 270 & 0 & - & + & - \\
\hline 48 & 270,000 & 0 & _- & + & _- \\
\hline 49 & $1,330,000$ & 0 & + & + & _- \\
\hline 50 & $4,200,000$ & 0 & - & + & - \\
\hline 51 & 20 & 0 & _- & + & _- \\
\hline 52 & $52,200,000$ & 0 & + & + & - \\
\hline 53 & 0 & 0 & + & + & - \\
\hline 54 & 61,000 & 0 & - & + & - \\
\hline 55 & $21,800,000$ & 0 & + & - & - \\
\hline 56 & $8,800,000$ & 0 & _- & + & _- \\
\hline 57 & $1,280,000$ & 0 & + & - & - \\
\hline 58 & $4,600,000$ & 0 & + & + & _- \\
\hline 59 & 5,300 & 0 & + & + & _- \\
\hline 60 & 95,000 & 0 & - & + & - \\
\hline 61 & 114,000 & 0 & + & - & - \\
\hline 62 & 720,000 & 0 & - & + & - \\
\hline 63 & 37,000 & 0 & _ & + & _ \\
\hline
\end{tabular}

+: Positive bacterial growth. -: Negative bacterial growth. GNAB: Gram-negative aerobic bacilli.
Between $8 \mathrm{~h}$ and $16 \mathrm{~h}$ after birth, 13 of the 23 samples showed growth of streptococci, ranging from 40 to $3,800,000$ cfu. S. epidermidis was detected in 16 samples, and only 1 sample showed growth of Gram-negative aerobic bacilli. Five samples did not show bacterial growth (Table 2).

Between $16 \mathrm{~h}$ and $24 \mathrm{~h}$ after birth, 23 of the 27 samples showed growth of streptococci, ranging from 20 to $52,200,000 \mathrm{cfu}$. Ten samples showed growth of $S$. aureus, and 21 samples showed growth of $S$. epidermidis. Gram-negative aerobic bacilli were detected in only 1 sample. Only 1 sample showed absence of bacterial growth (Table 3).

Between $24 \mathrm{~h}$ and $53 \mathrm{~h}$ after birth, all samples presented bacterial growth. Seventeen of the 18 samples showed growth of streptococci, ranging from 100 to $70,200,000$ cfu. Sixteen samples showed growth of $S$. epidermidis and 6 samples showed growth of S. aureus. Gram-negative aerobic bacilli were found in 2 samples (Table 4).

Mutans streptococci were not detected in any of the 81 samples analyzed, regardless of time after birth.

Table 4. Microbiological analysis of samples $(\mathrm{n}=17)$ between $24 \mathrm{~h}$ and $53 \mathrm{~h}$ after birth

\begin{tabular}{|c|c|c|c|c|c|}
\hline \multirow{2}{*}{ Samples } & \multicolumn{2}{|c|}{ streptococci } & \multicolumn{2}{|c|}{ staphylococci } & \multirow{2}{*}{ GNAB } \\
\hline & cfu & S. mutans & S. aureus & S. epidermidis & \\
\hline 64 & $37,800,000$ & 0 & - & + & - \\
\hline 65 & $19,000,000$ & 0 & - & + & - \\
\hline 66 & $4,200,000$ & 0 & - & + & - \\
\hline 67 & $9,400,000$ & 0 & + & + & - \\
\hline 68 & 0 & 0 & - & + & - \\
\hline 69 & $4,600,000$ & 0 & - & + & - \\
\hline 70 & $15,600,000$ & 0 & + & + & - \\
\hline 71 & $6,200,000$ & 0 & - & + & + \\
\hline 72 & $28,800,000$ & 0 & - & + & - \\
\hline 73 & $54,600,000$ & 0 & + & + & - \\
\hline 74 & $7,200,000$ & 0 & + & + & - \\
\hline 75 & $56,600,000$ & 0 & - & + & + \\
\hline 76 & $16,400,000$ & 0 & - & + & - \\
\hline 77 & $2,810,000$ & 0 & + & + & - \\
\hline 78 & $20,200,000$ & 0 & - & - & - \\
\hline 79 & 100 & 0 & - & - & - \\
\hline 80 & $9,600,000$ & 0 & + & + & - \\
\hline 81 & $70,200,000$ & 0 & - & + & - \\
\hline
\end{tabular}

+ : Positive bacterial growth. -: Negative bacterial growth. GNAB: Gram-negative aerobic bacilli. 


\section{Discussion}

Identification of the indigenous oral microbiota is complicated because the individual may have had contact with different types of microorganisms. The presence of these microorganisms may be transient in the oral cavity, depending on the conditions encountered during their metabolism and growth (9).

Previous studies have reported that the oral cavity of children is sterile until $10 \mathrm{~h} \mathrm{(14)}$ and $24 \mathrm{~h}$ (9) after birth and other findings point to an increase in the number of viable microorganisms between 6 and $10 \mathrm{~h}$ after birth (14). In the present study, only $30,7 \%$ of the samples showed bacterial growth between 10 min and $8 \mathrm{~h}$ after birth.

Silva et al. (4) identified $S$. aureus in the nostrils, mouth and anus of $49 \%$ of newborns. In this study, between 16 and $24 \mathrm{~h}$ after birth, S. aureus were present in $37.03 \%$ of the samples, and after $53 \mathrm{~h}$ of life, S. aureus were present in $33.3 \%$ of the samples, thereby showing a considerable risk of early infection. According to Zdrazilek et al. (2), $S$. aureus frequently colonize nipples and are regularly found in the umbilical stump and in eye and mouth corners of babies. Therefore, mothers should be instructed to wash their hands and then the nipples prior to breast-feeding to delay the colonization of $S$. aureus in newborns, who have immature immune systems. Although it is likely that the transmission of microorganisms may occur from the mother to the newborn, the microorganisms may also be transmitted via the hands of the nursing staff (20) and use of indwelling vascular catheters, high-calorie hyperalimentation infusions, and assisted ventilation (21).

The analysis of oral samples from 51 newborns at 1 and 8 days after birth revealed that approximately half of the children presented very low staphylococci levels (9). In this study, S. aureus, a pathogenic species, was detected in approximately $19.8 \%$ of the samples from newborns, possibly due to the contamination of the oral cavity by extrinsic sources, such as the attendants (8).

In the present study, S. epidermidis was the first microorganism to colonize newborn's oral cavity between 10 min and $8 \mathrm{~h}(30.7 \%)$ after birth, and the counts of this microorganism increased by approximately $90 \%$ after 53 $\mathrm{h}$ of neonatal life. According to Van Mellaert et al. (5), $S$. epidermidis, previously considered a human commensal, are now regarded as a frequent cause of nosocomial infections and the most common cause of device-related infections. Thus, early and intense infection caused by this microorganism in the first hours of life can be dangerous. Preventive hygienic measures should be strengthened and encouraged.

During the first year of life, streptococci, staphylococci, neisseria, lactobacilli, veillonella (9), actinomyces and fusobacteria (10) are the most prevalent microorganisms in the oral cavity of the infant (9). In this study, the most prevalent genera in the samples tested were streptococci in approximately $65.4 \%$ of the samples and staphylococci in approximately $75.3 \%$ of the samples. The present results agree with those of McCarthy et al. (9), demonstrating that streptococci make up $98 \%$ of the total bacteria in the first and second day of life. Streptococcus mitis biovar 1 and Streptococcus oralis were also detected in the oral cavity of newborns until 3 days after birth (22). S. mitis is considered as the major component of the oral streptococcal flora in infants at the end of the first year of life (12).

There is controversy regarding the colonization of the oral cavity in newborns by $S$. mutans. Some authors report that newborns $(12,23)$ do not harbor S. mutans on their mucous membranes, whereas there is a report demonstrating that $S$. mutans can be detected in children as young as 2 months old (24) and at 3 months of age (25), prior to tooth eruption (25). In the present study, S. mutans were not detected in the samples, and this result is in agreement with the several reports in the literature $(12,23)$.

The extent to which perinatal events influence the acquisition of indigenous microorganisms in the oral cavity remains unclear. Additional studies on the natural history of these indigenous microorganisms may provide general information on the indigenous biota. However, early colonization of newborn's oral cavity by many bacterial species in those who have immature immune systems can predispose them to a disease.

In conclusion, the number of bacterial species in the oral cavity of neonates increased over time. Streptococci and $S$. epidermidis were detected in nearly all samples in the evaluated time spam. S. aureus was detected in onethird of the samples, and the number of samples without any evidence of bacteria decreased from $69.3 \%$ in the first period of evaluation (between $10 \mathrm{~min}$ and $8 \mathrm{~h}$ after birth) to $0 \%$ in the last period of evaluation (between 24 and $53 \mathrm{~h}$ after birth). The adoption of strict hygienic measures by the mother and the nursing staff should be emphasized to delay the occurrence of infections caused by microorganisms in newborns. In addition, hospital procedures must be aseptic and invasive interventions must be minimized as much as possible.

\section{Resumo}

Os mecanismos de defesa do hospedeiro não estão bem desenvolvidos em neonatos. 0 objetivo deste estudo foi avaliar a dinâmica da colonização microbiana da cavidade oral em recém-nascidos. Oitenta e uma amostras da microbiota oral foram obtidas a partir de 51 recém-nascidos saudáveis, entre 10 min e $53 \mathrm{~h}$ após o nascimento, esfregando-se, suavemente, cotonetes esterilizados sobre a superfície da língua, mucosa bucal, processo alveolar e palato. Após o processamento microbiológico foi realizada a contagem de unidades formadoras de colônias de estreptococos, estafilococos e bacilos aeróbios Gram-negativos. Entre 10 min e $8 \mathrm{~h}$, Staphylococcus epidermidis foram detectados em 30,7\% das amostras; 
entre 8 e $16 h$, S. epidermidis foram detectados em $69,5 \%$ das amostras e streptococci foram detectados em 56,5\% das amostras. Entre 16 e $24 \mathrm{~h}, \mathrm{~S}$. epidermidis, streptococci e S. aureus foram detectados em 77,78\%, 85, $18 \%$ e $37,03 \%$ das amostras, respectivamente. Entre 24 e 53 h, S. epidermidis foram detectados em $88,89 \%$ das amostras, streptococci em $94,4 \%$ e $S$. aureus em 33,3\% das amostras. S. mutans não foram encontrados em nenhuma amostra. A adoção de medidas de higiene rigorosas por parte da mãe e da equipe de enfermagem deve ser enfatizada para evitar ou pelo menos retardar a ocorrência de infecções causadas por microorganismos em recém-nascidos. Adicionalmente, procedimentos hospitalares devem ser assépticos e intervenções invasivas devem ser minimizadas.

\section{Acknowledgements}

The authors are indebted to Dr. Izabel Yoko Ito (in memoriam) of the Department of Clinical Analyses, Toxicology and Bromatology, School of Pharmaceutical Sciences of Ribeirão Preto, University of São Paulo, for the invaluable collaboration during microbiological processing and analysis. The authors also acknowledge Jaqueline E. C. V. Menezes for her assistance during sample collection.

\section{References}

1. Rotimi VO, Duerden BI. The development of the bacterial flora in normal neonates. J Med Microbiol 1981;14:51-62.

2. Zdrazilek J, Petrás P, Srámová H, Subertová V, Masková L. Staphylococcus aureus at a maternity ward. I. Colonization of mothers and neonates and survival of various $S$. aureus types in colonized individuals. J Hyg Epidemiol Microbiol Immunol 1988;32:49-57.

3. Könönen E. Development of oral bacterial flora in young children. Ann Med 2000; 32:107-112.

4. Silva HA, Abdallah VOS, Carneiro CL, Gontijo Filho PP. Infection and colonization by Staphylococcus aureus in a high risk nursery of a Brazilian teaching hospital. Braz J Infect Dis 2003;7:381-386.

5. Van Mellaert L, Shahrooei M, Hofmans D, Eldere JV. Immunoprophylaxis and immunotherapy of Staphylococcus epidermidis infections: challenges and prospects. Expert Rev Vaccines 2012;3:319-334.

6. Bokulich NA, Mills DA, Underwood M. Surface microbes in the neonatal intensive care unit: changes with routine cleaning and over time. J Clin Microbiol 2013;51:2617-2624.

7. Marchant EA, Boyce GK, Sadarangani M, Lavoie PM. Neonatal sepsis due to coagulase-negative staphylococci. Clin Dev Immunol 2013 [Epub ahead of print. DOI: 10.1155/2013/586076].

8. Ross JM, Needham JR. Genital flora during pregnancy and colonization of the newborn. J R Soc Med 1980;73:105-110.

9. McCarthy C, Snyder ML, Parker RB. The indigenous oral flora of man. The newborn to the 1 year-old infant. Arch Oral Biol 1965;10:61-70.

10. MacFarlane TW, Samaranayake LP. Oral ecosystem and dental plaque. In: Clinical Oral Microbiology. Editor: Sayer L. London: Wright, 1989.

11. Brook I. Anaerobic infections in children. Adv Exp Med Biol
2011;697:117-152.

12. Smith DJ, Anderson JM, King WF, van Houte J, Tauhman MA. Oral streptococcal colonization of infants. Oral Microbiol Immunol 1993;8:1-4.

13. Cortelli JR, Aquino DR, Cortelli SC, Franco GCN, Fernandes CB, RomanTorres CVG et al. Detection of periodontal pathogens in oral mucous membranes of edentulous individuals. J Periodontol 2008;79:19621965.

14. Kosteka F. Relation of the teeth to the normal development of microbial flora in the oral cavity. The Dental Cosmos 1924; 66:927-935.

15. Tapia-Rombo CA, Ugarte-Torres RG, Alvarez-Vázquez E, Salazar-Acuña $\mathrm{AH}$. Risk factors for intrahospital infection in newborns. Arch Med Res 2001;32:304-311.

16. Coykendall AL. Classification and identification of the viridans streptococci. Clin Microbiol Rev 1989;2:315-328.

17. Gibbons RJ, Houte JV. Selective bacterial adherence to oral epithelial surfaces and its role as an ecological determinant. Infect Immun 1971;3:567-573.

18. Caufield PW, Dasanayake AP, Li Y, Pan Y, Hsu J, Hardin JM. Natural History of Streptococcus sanguinis in the oral cavity of infants: evidence for a discrete window of infectivity. Infect Immun 2000;68:4018-4023.

19. Saravia ME, Nelson-Filho $P$, Ito $I Y$, da Silva LA, Emilson CG. Morphological differentiation between S. mutans and S. sobrinus on modified SB-20 culture medium. Res Microbiol 2011;166:63-67.

20. Safdar N, Maki DG. The commonality of risk factors for nosocomial colonization and infection with antimicrobial-resistant Staphylococcus aureus, enterococcus, Gram-negative bacilli, Clostridium difficile, and Candida. Ann Intern Med 2002;136:834-844.

21. Baltimore RS. Neonatal nosocomial infections. Seminars in perinatology 1998;22:25-32.

22. Pearce C, Bowden GH, Evans M, Fitzsimmons SP, Johnson J, Sheridan $M J$, et al.. Identification of pioneer viridians streptococci in the oral cavity of human neonates. J Med Microbiol 1995;42:67-72.

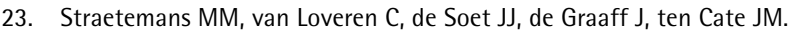
Colonization with mutans streptococci and lactobacilli and the caries experience of children after the age of five. J Dent Res 1998;77:18511855.

24. Tankkunnasombut S, Youcharoen $K$, Wisuttisak W, Vichayanrat S, Tiranathanagul S. Early colonization of mutans streptococci in 2- to 36-month-old Thai children. Pediatr Dent 2009;31:47-51.

25. Wan AK, Seow WK, Walsh L, Bird P, Tudehope DL, Purdie DM. Association of Streptococcus mutans infection and oral developmental nodules in pre-dentate infants. J Dent Res 2001;80:1945-1948.

Received May 5, 2013 Accepted July 13, 2013 